TAHKIM, Jurnal Peradaban dan Hukum Islam. Vol.2 No.l (Maret, 2019) | ISSN : 2597-7962

\title{
HUKUM KELUARGA DI DUNIA ISLAM \\ (PERBANDINGAN KITAB MAJALLATUL AHKAM DI TURKI DAN KOMPILASI HUKUM ISLAM DI INDONESIA)
}

\author{
Encep Abdul Rojak \\ Fakultas Syariah Universitas Islam Bandung \\ Abd.rozaq19@gmail.com
}

\begin{abstract}
ABSTRAK
Tatanan keluarga merupakan awal dari keberhasilan sebuah negara. Semakin baik hubungan dalam keluarga maka akan membentuk negara yang baik. Karena itu Negara harus hadir dalam mengatur kerukunan dan keharmonisan dalam keluarga. Turki dan Indonesia merupakan dua negara besar dan sebagian besar menganut agama Islam. Tata cara perkawinan harus diatur agar sesuai dengan hukum Islam. Kemudian kedua negara ini membuat aturan-aturan yang dibukukan melalui legislasi, bersumber dari ajaran Islam sebagai acuan dalam hukum keluarga yang bersifat aplikatif. Majallatul Ahkam di Turki dan Kompilasi Hukum Islam di Indonesia memberikan kepastian hukum yang jelas bagi para keluarga muslim. Tujuannya untuk dijadikan pedoman hukum bagi setiap keluarga di kedua negara ini.
\end{abstract}

Kata kunci: Hukum Keluarga, Legislasi, dan Perkawinan

\begin{abstract}
Family order is the beginning of the success of a country. The better relationship in the family will be a good country. Therefore the Nation must be present in regulating for harmony in the family. Turkey and Indonesia are two big countries and most of them religion is Islam. The marriage procedure must be arranged in accordance with Islamic law. Then these two countries made the rules that were recorded by legislation, sourced from Islamic law as a reference in applicable family law. Majallatul Ahkam in Turkey and Kompilasi Hukum Islam in Indonesia provide clear legal certainty for Muslim families. The goal is to become a legal guide for every family in these two countries.
\end{abstract}

Keywords: Family Law, Legislation, and Marriage

\section{A. PENDAHULUAN}

Islam merupakan agama yang sempurna. Salah satu kesempurnaannya terlihat dari aturan hukum yang harus diberlakukan oleh muslim (orang yang masuk Islam) dimana pun ia berada, karena hukum Islam berlaku secara sendirinya dan mengikat 
TAHKIM, Jurnal Peradaban dan Hukum Islam. Vol.2 No.l (Maret, 2019) | ISSN : 2597-7962

bagi orang yang telah menyatakan bahwa ia masuk Islam, walaupun ia berada di daerah kekuasaan non muslim.

Bentuk sebuah Negara bermacam-macam, ada negara Islam, negara muslim, dan negara sekuler. Negara Islam dan negara muslim masih ada kelonggaran bagi muslim untuk melaksanakan ritual ibadahnya dan Negara ikut memfasilitasinya, baik tentang ajaran hukumnya maupun fasilitas ibadahnya seperti masjid, dll. Dalam negara seperti model ini, muslim tidak akan menemukan kesukaran dalam mengaplikasikan hukum Islam dalam kesehariannya, seperti ibadah shalat, puasa, naik haji, termasuk pernikahan, dll. UUD 1945 Pasal 1 Ayat 3 menyebutkan bahwa Indonesia adalah Negara hukum. Karena itu, hukum Islam yang merupakan bagian dari sistem hukum yang berlaku di Indonesia.

Turki merupakan Negara yang sekuler pada saat ini, sehingga antara agama dan Negara ada dikotomi dan pembatasan. Selain itu, penduduk Negara Turki tidak sedikit yang memeluk Islam. Oleh karenanya, kedudukan hukum keluarga di Turki pada saat ini perlu dikaji lebih lanjut, apakah berdasarkan ajaran Islam atau tidak. Oleh karena itu, dalam makalah ini akan dibahas kajian hukum keluarga di Negara Turki, bandingannya dengan Negara Indonesia.

\section{B. PEMBAHASAN}

Islam merupakan agama samawi yang memiliki aturan-aturan yang bersumber dari wahyu, termasuk di dalamnya adalah aturan-aturan tentang kenegaraan. Aturanaturan dalam Islam ada yang secara tersurat langsung dalam al-Qur'an, yang lebih dikenal dengan Syari'ah dan ada juga yang memerlukan ijtihad ulama' yang menghasilkan karya mujtahid yang dikenal dengan fiqh.

\section{Syari'ah}

Secara etimologi kata syari'ah memiliki banyak arti sesuai dengan uslub kalimatnya itu sendiri. Kata syari'ah bisa berarti ketetapan dari Allah bagi hambahamba-Nya, jalan tempat keluarnya air untuk minum, ${ }^{1}$ dan jalan lurus yang harus dituruti. ${ }^{2}$ Ini menandakan bahwa kata syari'ah memiliki arti yang beragama.

\footnotetext{
${ }^{1}$ Abdul Wahab Khalaf, Searah Pembentukan dan Perkembangan Hukum Islam, (Jakarta: PT Raja Grafindo Persada, 2002), hlm. 1.

2 Jaih Mubarok, Sejarah dan Perkembangan Hukum Islam, (Bandung: PT Remaja Rosdakarya, 2003), hlm. 3
} 
TAHKIM, Jurnal Peradaban dan Hukum Islam. Vol.2 No.l (Maret, 2019) | ISSN : 2597-7962

Kemudian, syari'ah secara terminologi Manna' al-Qathan memberikan definisi segala ketentuan Allah yang disyari'atkan bagi hamba-hamba-Nya baik menyangkut akidah, ibadah, akhlak maupun mu'amalah. ${ }^{3}$ Mahmud Syaltut memberikan definisi hukum-hukum dan tata aturan yang Allah syari'atkan bagi hamba-Nya untuk diikuti. ${ }^{4}$ Dan menurut Faruq Nabhan segala sesuatu yang disyari'atkan Allah kepada hamba-hamba-Nya. ${ }^{5}$

Dari beberapa pengertian di atas, dapat diambil titik benang merahnya bahwa Syari'ah adalah hukum yang bersumber dari Allah Swt. yang mengikat kepada seluruh hambanya, baik yang bersumber pada al-qur'an maupun hadis. Karena syari'ah itu disyariatkan untuk hambanya, maka manusia seharusnya menjalankan segala hukum yang sudah ditetapkan oleh Allah Swt.

\section{Taqnin}

Qanun atau taqnin/qanun berasal dari bahasa yunani yang diadopsi menjadi bahasa arab melalui bahasa suryani, yang berarti "alat pengukur" dan "kaidah". Dalam bahasa arab kata tersebut berubah menjadi qanna yang berarti membuat hukum (to make law, to legislate). Padanan katanya, qanun dapat berarti juga sebagai hukum (law), peraturan (rule, regulation), undang-undang (statute, code). ${ }^{6}$ Dalam Al-Ahkam al-Sulthaniyyah, karya dari imam Al-Mawardi (w. 450H/1058M), menggunakan kata qanun dalam beberapa kesempatan, seperti qawanin al-siyasah, hifdz al-qawanin al-syar'iyyah wa harasat al-ahkam aldiniyah, al-qawanin al-muqarrarah, dan sebagainya. Ini menandakan bahwa qanun memiliki konotasi yang berbeda. ${ }^{7}$

${ }^{3}$ Roibin, Penetapan Hukum Islam dalam Lintasan Sejarah, (Malang: UIN-Maliki Press, 2010), hlm. 10

${ }^{4}$ Ibid.

${ }^{5}$ Ibid, hlm. 4

${ }^{6}$ A. Qodri A. Azizy, Hukum Nasional: Eklektisisme Hukum Islam \& Hukum Umum, (Jakarta: Teraju, 2004), hlm. 75

7 Ibid. 
TAHKIM, Jurnal Peradaban dan Hukum Islam. Vol.2 No.l (Maret, 2019) | ISSN : 2597-7962

Taqnin dalam istilah lainnya disebut juga dengan legislasi. Rousseau mendefinisikan legislasi sebagai berikut: ${ }^{8}$

"Legislation is an expression of the general will, such that a free people is only bound by the laws wich they have made for themselves"

Dalam perkembangan sejarah, Dinasti Usmani yang berikutnya menjelma menjadi Negara Turki merupakan salah satu Negara yang telah melakukan legislasi/taqnin dalam hukum Islam. Melalui kitab hukum Majallat al-Ahkam alAdhliyah merupakan kulminasi usaha kodifikasi hukum dalam sebuah dinasti Usmani. $^{9}$

Di Indonesia, hukum Islam yang sudah di qonunkan dalam tata hukum adalah bidang hukum perdata (Islam), khususnya bidang hukum keluarga. Seperti hukum perkawinan yang tercantum dalam KHI Buku I, UU RI No 41 tahun 2004 tentang Wakaf, dsb. Dalam bidang hukum pidana, hukum Islam belum bisa menjelma menjadi undang-undang yang mengatur seluruh masyarakat Indonesia, termasuk umat Islam, sehingga seakan-seakan bidang hukum tersebut bukan menjadi urusan umat Islam Indonesia.

\section{Hukum Keluarga di Turki}

Turki merupakan sebuah Negara sekuler yang didalamnya terdapat penduduk muslim.

\section{a. Viewlook Negara Turki}

Negara Turki lahir dari reruntuhan kesultanan Usmaniyah pasca perang dunia I yang terletak di Asia kecil (Anatolia) yang didirikan oleh Mustofa Kemal Attaturk. Turki merupakan negara sekuler pertama di dunia Islam. Negara yang berdekatan dengan benua eropa ini memproklamirkan diri sebagai Negara Republik pada tahun 1923. ${ }^{10}$ Turki merupakan Negara yang termasuk kepada daratan Eropa Tenggara dan Asia kecil, berbatasan dengan Georgia, Armenia, Azerbaijan, dan Iran di timur, Irak, Suriah dan laut tengah di selatan, laut hitam di utara, laut Aegea di Barat, dan Yunani di barat laut. Luas Negara

${ }^{8}$ Jazuni, Legislasi Hukum Islam di Indonesia, (Bandung: Citra Aditya Bakti, 2005), hlm. 33

${ }^{9}$ Ibid. hlm. 41

${ }^{10}$ John. L. Esposito, Ensiklopedi Oxford Dunia Islam, alih bahasa Eva Yn. dkk.(Bandung: Mizan, 2001), hlm. 63 
TAHKIM, Jurnal Peradaban dan Hukum Islam. Vol.2 No.l (Maret, 2019) | ISSN : 2597-7962

sebesar $779.452 \mathrm{~km} 2$, diantaranya $755.688 \mathrm{~km} 2$ di Asia kecil (Semenanjung Anatolia) dan 23.764 km2 di Eropa Tenggara. Jumlah Penduduk sebanyak 56.941 .000 (1990), sebagian besar warga negaranya termasuk etnis Turki asli. Agama yang dipeluk masyarakatnya adalah Islam (98\%). Dan Ibu kota negaranya adalah kota Ankara. Persinggungan Islam dengan Turki melalui sejarah panjang, terhitung sejak abad pertama hijriah hingga suku-suku Turki menjadi penganut dan pembela Islam. ${ }^{11}$

Dalam periode 1960-1978, angka rata-rata kenaikan GNP perkapita Turki mencapai 3,6 persen/tahun. Ini merupakan hasil capaian yang luar biasa dan sukses besar. Sementara itu pertambahan penduduk Turki sangat tinggi. Pada tahun 1940 penduduknya berjumlah 17 juta, maka kini mencapai 56.941.000 jiwa. Turki merupakan satu-satunya negara Timur Tengah yang memiliki dua kota besar yang berkembang dengan rata-rata diatas $5 \%$ per tahun. Ketika politik multi partai diperkenalkan di Turki pada tahun 1946, dakwaan bahwa umat Islam tidak dapat beribadah dengan bebas muncul secara menonjol diantara tuduhan-tuduhan yang dilemparkan kepada Parta Rakyat Republik yang telah berkuasa selama 27 tahun. Dakwaan ini datang dari sejumlah partai politik yang baru saja terbentuk dengan suatu ideologi Islam yang samar-samar sebagai dasarnya. Partai-partai itu antara lain:

1) Partai Pembangunan Nasional (Party of National Development)

2) Partai Keadilan Sosial (Party of Social Justice)

3) Partai Tani (the cultivator peasent party)

4) Partai Pembela Kemurnian (party of purification protection)

5) Partai Konservatif Turki (Turkish conservative Party)

Akan tetapi setelah pemilu tahun 1950 (pemilu bebas pertama Turki) semua partai itu harus bubar secara cepat atau lambat karena tidak memiliki dukungan pemilih. ${ }^{12}$

b. Implementasi Hukum Islam di Turki

Ketika Imperium kerajaan Usmani masih berkuasa, imperium memberlakukan sistem yudisial dan legal yang digabungkan dengan syariah

${ }^{11}$ Van Hoeve, Ensiklopedi Islam, (Jakarta: PT. Ichtiar Baru, 1994), hlm.114

${ }^{12}$ Ibid. 
TAHKIM, Jurnal Peradaban dan Hukum Islam. Vol.2 No.l (Maret, 2019) | ISSN : 2597-7962

khususnya yurisprudensi mazhab Hanafi, dimana pengadilan diarahkan untuk menerapkan keputusan berbagai kasus. Sistem ini ditopang oleh lembaga keagamaan yang hampir independen dari kekuasaan sultan (kepala pemerintahan) pada saat itu. ${ }^{13}$

Sultan tidak boleh sewenang-wenang memberlakukan hukum syariah tanpa legitimasi berupa fatwa dari lembaga mufti. Dipihak lain, mufti memiliki kewenangan untuk memilih para hakim yang mengatur pemberlakuan syariah di seluruh wilayah kerajaan. Namun pada masa abad 19, bersamaan dengan lengsernya kekuasaan Turki Usmani, semua lembaga-lembaga keagamaan ini tidak lagi diberlakukan. Pada saat inilah kekuasaan Negara berpindah haluan menjadi sekuler.

Agama dalam tradisi masyarakat Turki mempunyai peranan besar dalam lapangan sosial dan politik. Masyarakat digolongkan berdasarkan agama. Kerajaan sendiri sangat terikat dengan syari'at sehingga fatwa ulama menjadi hukum yang berlaku. Oleh karena itu, ulama mempunyai tempat tersendiri dan berperan besar dalam kerajaan dan masyarakat. Tanpa legitimasi mufti, keputusan hukum kerajaan bisa tidak berjalan. ${ }^{14}$

Untuk sistematisasi serta kodifikasi sistem hukum, pada tahun 1839 dikeluarkan dekrit Imperium Hatt-I Syarif sebagai pondasi bagi rezim legislatif modern. Revolusi politik yang telah memporak-porandakan wilayah imperium Usmani dan melengserkan jabatan khalifah ikut memberi dampak terhadap penggantian UU sipil tahun 1876 dan hukum keluarga yang baru ditetapkan pada tahun 1915 dan 1917, serta hukum waris dalam mazhab Hanafi yang belum sempat terkodifikasi dengan UU sipil pada tahun 1926. Perkembangan hukum Islam di Turki dibagi oleh Harun Nasution ke dalam tiga periode besar yaitu periode awal (650-1250), periode pertengahan (1250-1800), dan periode modern (1800 sampai sekarang). ${ }^{15}$

Pada periode awal, syari'at Islam dilaksanakan dengan murni sesuai dengan ajaran Alquran dan sunnah. Sedangkan pada periode pertengahan sudah

${ }^{13}$ Atho muzdhar \& Khairuddin Nasution, Hukum Keluarga Muslim... hlm. 37

${ }^{14}$ Badri Yatim, Sejarah Peradaban Islam, (Jakarta: PT. Raja Grafindo Persada, 1999), hlm.

${ }^{15}$ Harun Nasution, Pembaharuan dalam Islam; Sejarah Pemikiran dan Gerakan, (Jakarta: Bulan Bintang, 1991, Cet. VIII), hlm. 12-13 
TAHKIM, Jurnal Peradaban dan Hukum Islam. Vol.2 No.l (Maret, 2019) | ISSN : 2597-7962

ada usaha untuk memasukkan hukum Islam ke dalam perundang-undangan negara yaitu ketika khalifah al-Manshur menyerukan untuk membuat suatu undang-undang yang diambil dari Alquran dan Sunnah yang berlaku untuk semua negeri. ${ }^{16}$ Usaha ini dilakukan setelah melihat adanya perbedaan pendapat dikalangan fuqaha dan perbedaan putusan dikalangan hakim-hakim dalam memutuskan suatu persoalan yang sama. Usaha tersebut tidak berhasil karena para fuqaha tidak ingin memaksakan pendapatnya untuk diikuti dan karena menyadari bahwa ijtihad yang dilakukannya bisa saja salah.

Usaha Khalifah al-Manshur tidak sia-sia, yaitu baru terwujud setelah munculnya kitab Al-Majallah al-Ahkam al-Adliyah ${ }^{17}$ pada tahun 1823. Dengan demikian dikeluarkanlah keputusan pemerintah Turki Usmani untuk memakai kitab undang-undang tersebut sebagai pegangan para hakim di pengadilanpengadilan.

Kitab Al-Majallah al-Ahkam al-Adliyah terdiri dari 185 Pasal yang dibagi menjadi 16 bab. Yaitu: 1) Jual beli, 2) Sewa menyewa, 3) Tanggungan, 4) Pemindahan utang atau piutang, 5) Gadai, 6) Titipan, 7) Hibah, 8) Rampasan, 9) Pengampunan, paksaan dan hak beli dengan paksa, 10) Serikat dagang, 11) Perwakilan, 12) Perdamaian dan pembebasan hak, 13) Pengakuan, 14) Gugatan 15) Pembuktian dan sumpah, 16) Peradilan. Dengan demikian kitab UndangUndang ini merupakan kitab Undang-Undang Hukum Perdata Umum (positif) pertama yang diambil dari ketentuan hukum Islam, dan diambil dari mazhab Hanafi sebagai mazhab resmi negara pada waktu itu.

Selain kitab tersebut di atas, juga dikeluarkan Undang-Undang Keluarga (Qanun 'Ailat) pada tahun 1326, yang dikhususkan untuk masalah-masalah kawin dan putusnya perkawinan. ${ }^{18}$ Dalam Undang-Undang ini, banyak ketentuan-ketentuannya yang tidak diambil dari mazhab Hanafi, seperti tidak sahnya perkawinan orang yang dipaksa dan tidak sahnya talaq yang dijatuhkannya. Keluarnya kedua Undang-Undang tersebut merupakan

\footnotetext{
${ }^{16}$ Ahmad Hanafi, Pengantar dan Sejarah Hukum Islam, Cet. V (Jakarta: PT. Bulan Bintang, 1989), hlm. 216

${ }^{17}$ Kodifikasi hukum Majallah al-ahkam al adhiya mempunyai makna yang penting dalam sejarah yang dikenal sebagai kodifikasi hukum islam yang pertama yang bersumber pada syariáh. Kodifikasi tersebut mulai terbuka dengan tidak semata-mata mendasarkan pada mazhab Hanafi.
}

${ }^{18}$ Ibid. hlm. 221 
TAHKIM, Jurnal Peradaban dan Hukum Islam. Vol.2 No.l (Maret, 2019) | ISSN : 2597-7962

kodifikasi hukum pertama yang bersumber pada syari'at Islam. ${ }^{19}$ dan sebagai langkah pertama untuk meninggalkan taqlid buta dan untuk tidak terikat dengan satu mazhab tertentu, baik dalam bentuk keputusan hakim, maupun dalam pendapat orang biasa. Pada akhir periode pertengahan mulai muncul pemikiran pembaharuan. Hal ini karena mulai adanya penetrasi Barat (Eropa) terhadap dunia Islam. Namun ide-ide pembaharuan itu mendapat tantangan dari kaum ulama, karena bertentangan dengan faham tradisionalis yang terdapat di kalangan umat Islam. Kaum ulama dalam menentang usaha tersebut menjalin kerjasama dengan Yeniseri. ${ }^{20} \mathrm{Hal}$ ini membuat gagalnya usaha pembaharuan pertama di Kerajaan Usmani.

Pada periode modern, usaha pembaharuan kedua dimulai yaitu setelah Yeniseri berhasil ditumpas oleh Sultan Mahmud II (1808-1830) pada tahun 1826. pembaharuan inilah yang pada akhirnya membawa perubahan besar di Turki. Langkah awal yang dilakukan Sultan Mahmud II dalam usaha pembaharuan adalah dengan merombak tradisi aristokrasi menjadi demokrasi. Gelar Sultan dipakai sebagai penguasa duniawi, dan Khalifah sebagai kepala rohaniah umat Islam. ${ }^{21}$ Dengan demikian raja mempunyai dua bentuk kekuasaan yaitu kekuasaan memerintah negara dan kekuasaan menyebarkan dan membela Islam.

Dalam melaksanakan kedua kekuasaan tersebut, Sultan dibantu oleh Sadrazam untuk urusan pemerintahan dan Syaikh al-Islam untuk urusan keagamaan. Namun kemudian, kedudukan Sadrazam ini dihapus dan diganti dengan jabatan Perdana Menteri yang membawahi menteri-menteri dan sebagai penghubung antara para menteri dan Sultan. Sedangkan kekuasaan yudikatif yang berada di tangan Sadrazam dahulu, dipindahkan ke tangan Syaikh alIslam. Tetapi dalam sistem baru ini, di samping hukum syari'at diadakan pula hukum sekuler, dan Syaikh al-Islam hanya menangani hukum syari'at, sedangkan hukum sekuler diserahkan kepada Departemen Perancang Hukum. ${ }^{22}$

\footnotetext{
${ }^{19}$ J. N. D. Anderson, Islamic Law in the Moderen World, diterjemahkan oleh Mahmud Husain dengan judul Hukum Islam di Dunia Modern Cet. I, (Yogyakarta: Tiara Wacana Yogya, 1994), hlm. 28

${ }^{20}$ Harun Nasution, pemembaharuan.., hlm. 18

${ }^{21}$ Ibid., hlm. 92

${ }^{22}$ Ibid., hlm. 93 
TAHKIM, Jurnal Peradaban dan Hukum Islam. Vol.2 No.l (Maret, 2019) | ISSN : 2597-7962

Sultan inilah yang pertama di kerajaan Usmani mengadakan perbedaan antara urusan agama dan urusan dunia yang pada masa selanjutnya membawa kepada adanya hukum sekuler di samping hukum-hukum syariat.

Sebagai lanjutan dari usaha-usaha pembaharuan yang dijalankan oleh Sultan Mahmud II, muncullah sebuah periode yang dikenal dengan nama Tanzimat yang dalam bahasa Turki dikenal dengan nama Tanzimat-i Khairiye (Tanzimat $^{23}$ yang di dalamnya menghendaki pembentukan sistem konstitusi dan parlemen. Periode ini bertujuan untuk memperlancar proses pembaharuan dan dimulai dengan diumumkannya deklarasi Gulkhane pada tanggal 3 Nopember 1839. Deklarasi ini menjelaskan syariat Islam dan Undang-Undang Negara pada awal masa kerajaan dipatuhi sehingga kerajaan menjadi besar dan kuat, serta rakyat hidup makmur. Tetapi setelah 150 tahun terakhir tak diperhatikan lagi, sehingga kemakmuran hilang, kemiskinan dan kebebasan negara lenyap dan lemah. Oleh karena itu, perlulah diadakan perubahan yang akan membawa kepada pemerintahan yang baik.

Selanjutnya dijelaskan bahwa seorang tertuduh akan diadili secara terbuka, ahli waris dari yang kena hukuman pidana tidak boleh dicabut haknya untuk mewarisi dan harta yang kena hukum pidana tidak boleh disita. Dan atas dasar piagam ini terjadi pula pembaharuan dalam bidang hukum, di mana Dewan Hukum yang dibentuk oleh Sultan diperbanyak anggotanya dan diberi kekuasaan membuat Undang-Undang. ${ }^{24}$ Kodifikasi hukum dimulai dan sebagai sumber hukum di samping syari'at, dipakai juga sumber-sumber di luar agama, di antaranya hukum Barat. Dan pada tahun 1840, keluarlah hukum pidana baru dan hukum dagang baru pada tahun 1850. Dan pada tahun 1847 didirikan mahkamah-mahkamah baru untuk urusan pidana dan sipil.

Sebagai tindak lanjut dari deklarasi Gulkhane, diumumkanlah Khatt-i Humayun pada tanggal 18 Pebruari $1856 .{ }^{25}$ yang lebih banyak mengandung pembaharuan terhadap kedudukan Eropa karena desakannya, dan tujuannya

\footnotetext{
${ }^{23}$ Tanzimat adalah gerakan pembaharuan di Turki yang diperkenalkan ke dalam sistem birokrasi dan pemerintahan Turki Usmani semenjak pemerintahan Sultan Abd al-Majid (1839-1861), putra Sultan Mahmud II, dan Sultan Abd al-'Aziz (1861-1876). Lihat Syafiq A. Mughni, Sejarah Kebudayaan Islam di Turki, Cet. I, (Jakarta: PT. Logos Wacana Ilmu, 1997), hlm. 125

${ }^{24}$ Harun Nasution, pembaharuan.. hlm. 100

${ }^{25}$ Ibid., hlm. 126 
TAHKIM, Jurnal Peradaban dan Hukum Islam. Vol.2 No.l (Naret, 2019) | ISSN : 2597-7962

adalah untuk memperkuat jaminan yang tercantum dalam piagam Gulkhane. Selanjutnya masyarakat non-muslim bebas melakukan pembaharuan tanpa ada perbedaan, dan kebebasan beragama dijamin dengan tidak memaksakan merubah agama. Perkara yang timbul antara orang yang berlainan agama diselesaikan oleh mahkamah campuran, serta perbedaan pajak yang dipungut dari rakyat dihapuskan.

Dengan demikian, kedua piagam yang menjadi dasar pembaharuan tanzimat mengandung faham sekularisme dalam berbagai institusi kemasyarakatan, terutama dalam institusi hukum. Hukum baru yang disusun banyak dipengaruhi oleh hukum Barat, seperti hukum pidana dan hukum dagang.

\section{c. Implmentasi Hukum Keluarga Turki}

Pada tahun-tahun sebelumnya, di Negara Turki untuk kasus-kasus yang berkaitan dengan status perseorangan, hubungan keluarga dan waris, telah diatur oleh pemerintah Usmani secara formal dengan mengadopsi hukum dari mazhab Hanafi, tetapi hanya berlangsung sampai tahun 1915, perubahan terjadi karena tuntutan perubahan kondisi sosial yang terjadi, sekalipun upaya untuk merealisasikannya dilakukannya secara bertahap. Turki merupakan Negara yang pertama kali melakukan pembaruan hukum keluarga pada tahun 1915 . Sebelum hukum keluarga diundangkan, hukum-hukum yang lain yang tercantum dalam Majallah al-Ahkam al-Adhliya sudah diundangkan. Kitab undang-undang ini sudah disiapkan jauh sebelum undang-undang hukum keluarga, yaitu pada tahun $1876 \mathrm{M}$. yang pada saat itu belum tercantum hukum keluarga di dalamnya. Turki Usmani telah melakukan legislasi hukum-hukum baru untuk melengkapi hukum Islam dalam skala besar telah pada abad ke-10 H/16 M yang menghasilkan qanun (canon). Qanun adalah hukum produk kesultanan dengan metode penetapan yang ketat dan bukan produk kekhalifahan. ${ }^{26}$

Di Turki, pembaruan hukum Islam dalam perundang-undangan hukum keluarga dimulai pada tahun 1917 dengan disahkannya the ottoman law of

${ }^{26}$ Ibid. hlm. 109 
TAHKIM, Jurnal Peradaban dan Hukum Islam. Vol.2 No.l (Maret, 2019) | ISSN : 2597-7962

family rights (Undang- undang tentang hak-hak keluarga) oleh Pemerintah Turki. ${ }^{27}$ Pembaruan hukum keluarga di Turki merupakan tonggak sejarah pembaruan hukum keluarga di dunia Islam dan mempunyai pengaruh yang besar terhadap perkembangan hukum keluarga di negara-negara lain.

Aturan hukum yang berkaitan dengan perkawinan dan perceraian mulai dirintis tahun 1915. Materi perubahan pada tahun tersebut adalah kewenangan (hak) untuk menuntut cerai yang menurut mazhab Hanafi hanya menjadi otoritas suami. ${ }^{28}$ Seorang isteri yang ditinggal pergi oleh suaminya selama bertahun-tahun atau suaminya mengidap penyakit jiwa ataupun cacat badan tidak dapat dijadikan dasar bagi isteri untuk meminta cerai dari suaminya. Ini menunjukkan perubahan tentang hukum keluarga yang berlaku di Turki.

Hukum tentang hak-hak keluarga (The Ottoman Law of Family Rights / Qanun al-huquq al Aila) yang dirintis sejak tahun 1915, kemudian diundangkan pada tahun 1917. Hukum keluarga ini merupakan hukum keluarga yang diundangkan pertama kali di dunia Islam. Hukum tentang hak-hak keluarga tahun 1917 yang dikeluarkan oleh Pemerintahan Turki Usmani mengatur tentang hukum perorangan dan hukum keluarga (tidak termasuk waris, wasiat dan hibah). Undang-undang ini bersumber pada berbagai mazhab sunni. Hukum tentang hak-hak keluarga tahun 1917 dalam bagian tertentu berlaku bagi golongan minoritas Yahudi dan Nasrani, karena undang-undang tersebut dimaksudkan untuk menyatukan yurisdiksi hukum pada pengadilan-pengadilan nasional. ${ }^{29}$ Undang-undang yang terdiri dari 156 Pasal ini hanya berlaku singkat selama dua tahun, namun munculnya undang-undang ini memberikan inspirasi bagi negara lain untuk mengadopsinya dengan beberapa modifikasi.

27 J.N.D. Anderson, Hukum Islam di Dunia Modern, alih bahasa Machnun Husein (Surabaya:Amar Press, 1990), hlm. 27 Lihat pula Tahir Mahmood, Family Law Reform in the Moslem World (Bombay: N.M.TRIPATHI PVT. LTD, 1972), hlm. 17

${ }^{28}$ Talak yang diucapkan suami dalam keadaan mabuk, di bawah ancaman, gurauan, sekedar menakut-nakuti, bahkan dalam keadaan mimpi atau keadaan tidak sadar karena sakit menurut mazhab Hanafi tetap sah dan mempunyai kekuatan hukum. Suami dapat menceraikan isterinya kapanpun ia kehendaki, dan isteri dapat dicerai oleh suaminya, meskipun isteri tersebut tidak menghendaki cerai sama sekali. Para isteri yang merasa terikat oleh mazhab Hanafi tersebut yang justru pertama kali mendesak pemerintah Tur $\underline{1}$ D untuk melakukan pembaruan hukum keluarga. Lihat J.N.D. Anderson, Hukum Islam..., hlm. 57-58.

${ }^{29}$ Ibid. 
TAHKIM, Jurnal Peradaban dan Hukum Islam. Vol.2 No.l (Maret, 2019) | ISSN : 2597-7962

Pada tahun 1917, situasi politik di Turki memberikan peluang untuk melakukan pembaruan hukum. Pasca konferensi Perdamaian Lausanne tahun 1923, Turki membentuk komisi hukum yang bertugas mempersiapkan hukum perdata baru. Komisi tersebut berusaha menempatkan Hukum tentang hak-hak keluarga tahun 1917, Majallah al-Ahkam al-Adhiya tahun 1876 dan hukum tradisional yang tidak tertulis kedalam hukum baru yang menyeluruh.

Usaha komisi hukum tersebut gagal dan dibubarkan akibat perbedaan pendapat yang tajam di kalangan modernis dan tradisional - seperti pengambilan materi dari mazhab yang berbeda dalam hukum Islam, yang bersumber dari hukum adat atau hukum luar.

Akibat dari pembubaran komisi hukum tersebut, terjadilah kekosongan hukum. Untuk mengisi kekosongan hukum pasca kegagalan komisi hukum tersebut, Pemerintah Turki mengadopsi hukum perdata Swiss tahun 1912 (The civil code of Switzerland, 1912) dengan beberapa perubahan yang disesuaikan dengan kondisi Turki dan diundangkan dalam hukum perdata Turki tahun 1926 (The Turkish civil code of 1926). Dalam beberapa hal ketentuan dalam hukum perdata Turki tahun 1926 sangat menyimpang dari hukum Islam tradisonal, seperti ketentuan waris dan wasiat yang mengacu pada hukum perdata Swiss tahun $1912 .^{30}$

Materi yang menonjol dalam hukum perdata Turki tahun 1926 adalah:

1) Ketentuan-ketentuan tentang pertunangan (terutama masalah taklik talak),

2) Batasan usia minimal menikah,

3) Hal yang menyebabkan dilarangnya menikah,

4) Hal yang berkaitan dengan poligami,

5) Keharusan mencatat perkawinan,

6) Tentang pembatalan perkawinan, perceraian, dan lain-lain.

Terkait dengan perceraian, diantaranya yaitu diatur pada Pasal $129-138$ Hukum Perdata Turki tahun 1926. Suami atau isteri yang terikat dalam sebuah hlm. 95-96

30 Tahir Mahmood, Family Law..., hlm. 17-18.lihat pula J.N.D. Anderson, Hukum Islam..., 
TAHKIM, Jurnal Peradaban dan Hukum Islam. Vol.2 No.l (Maret, 2019) | ISSN : 2597-7962

ikatan perkawinan dapat mengajukan perceraian kepada pengadilan dengan alasan yang telah ditentukan sebagai berikut:

1) Salah satu pihak berbuat zina.

2) Salah satu pihak melakukan percobaan pembunuhan atau penganiayaan berat terhadap pihak lainnya.

3) Salah satu pihak melakukan kejahatan atau perbuatan tidak terpuji yang mengakibatkan penderitaan yang berat dalam kehidupan rumah tangga.

4) Salah satu pihak meninggalkan tempat kediaman bersama (rumah) tiga bulan atau lebih dengan sengaja dan tanpa alasan yang jelas yang mengakibatkan kerugian di pihak lain.

5) Salah satu pihak menderita penyakit jiwa sekurang-kurangnya 3 tahun atau lebih yang mengganggu kehidupan rumah tangga dan dibuktikan dengan surat keterangan ahli medis (dokter).

6) Terjadi ketegangan antara suami isteri secara serius yang mengakibatkan penderitaan.

Seiring dengan perkembangan zaman Hukum Perdata Turki tahun 1926 mengalami dua kali proses amandemen. Amandemen tahap pertama terjadi pada kurun waktu 1933-1956. hasil amandemen ini antara lain berkaitan dengan ganti kerugian, dispensasi kawin, pasangan suami isteri diberi kesempatan untuk memperbaiki hubungan ketika pisah ranjang, juga penghapusan segala bentuk perceraian di luar pengadilan, serta tersedianya perceraian di pengadilan yang didasarkan pada kehendak masing-masing pihak (Pasal 125-132). Di samping itu pembayaran ganti kerugian terhadap pihak yang dirugikan akibat perceraian dapat dilaksanakan jika didukung dengan fakta dan keadaan kuat.

Proses amandemen kedua terhadap Hukum Perdata Turki tahun 1926 berlangsung pada tahun 1988-1992. Amandemen tahun 1988 memberlakukan perceraian atas kesepakatan bersama (divorce by mutual consents), nafkah istri dan penetapan sementara selama proses perceraian berlangsung. Amandemen 
TAHKIM, Jurnal Peradaban dan Hukum Islam. Vol.2 No.l (Maret, 2019) | ISSN : 2597-7962

tahun 1990 berkaitan dengan pertunangan, pasca perceraian dan adopsi. Proses amandemen yang dilakukan oleh legislatif tersebut berakhir tahun $1992 .{ }^{31}$

Materi amandemen tahun 1990 yang berkaitan dengan perceraian, antara lain :

1) Salah satu pihak dapat mengajukan cerai atas dasar perwujudan dari ketidakcocokan tabiat yang berakibat pada rumah tangga yang tidak bahagia.

2) Pihak yang tidak bersalah dan menderita berhak mengajukan cerai dan meminta ganti rugi yang layak dari pihak lain.

3) Pihak yang tidak bersalah dan menjadi miskin berhak mengajukan cerai dan meminta nafkah dari pihak lain selama setahun.

\section{d. Hambatan dan Tantangan}

Gerakan tanzimat menumbuhkan bibit nasionalisme Turki di kemudian hari melalui gerakan Usmani Muda dengan berkeyakinan bahwa Turki hanya dapat dipertahankan apabila mengadopsi peradaban yang berkembang di Eropa. Mereka mengharapkan proses transformasi sistem pemerintahan kerajaan Turki dari sistem otokrasi-monarkis menjadi monarki konstitusional, dengan memberikan kepada mereka otonomi pemerintahan dan kebudayaan. Dan sebagai dampak nyata dari ideologi nasionalisme adalah runtuhnya sistem khilafah Usmani yang dibangun atas pemikiran politik keagaman yang bersifat supra nasional. Tokoh utama gerakan nasionalime ini adalah Mustafa Kemal.

Pembaharuan yang pertama dilakukan Mustafa Kemal ditujukan terhadap bentuk negara yang sekuler, dimana pemerintahan harus dipisahkan dari agama dan kedaulatan terletak di tangan rakyat. Ide ini telah diterima dalam sidang Majelis Nasional Agung (MNA) pada tahun 1920. dan pada tahun 1921 disusunlah satu konstitusi yang menjelaskan bahwa kedaulatan adalah milik rakyat. Dengan demikian, yang berdaulat di Turki bukan lagi Sultan tetapi raktat. Kemudian pada tahun 1922, dalam sidang MNA, kekuasaan khalifah dan sultan berangsur-angsur dikurangi dengan memisahkannya, yang kemudian satu persatu dihapus dan mendirikan sebuah negara yang berbentuk

${ }^{31}$ Tahir Mahmood, Status of Personal Law in Islamic Countries: History, Texts and Analysis, Revised Edition (New Delhi:ALR, 1995), hlm. 84 
TAHKIM, Jurnal Peradaban dan Hukum Islam. Vol.2 No.l (Maret, 2019) | ISSN : 2597-7962

Republik pada tanggal 23 oktober 1923. Dan sebagai imbalan atas usul golongan Islam, maka ditambahkan satu artikel yang mengatakan bahwa agama Negara Republik Turki adalah Islam. ${ }^{32}$ Hal ini berarti bahwa kedaulatan bukan sepenuhnya terletak di tangan rakyat, tetapi juga pada syari'at.

Akan tetapi, Reformasi Mustafa Kemal dibidang hukum yang merupakan kebijakan untuk memisahkan Islam dari urusan keagamaan, mulai menghilangkan institusi keagamaan yang ada dalam pemerintahan, seperti; dihapuskannya Biro Syaikh al-Islam dan Mahkamah Syari'at pada tanggal 18 April 1924, dan hukum syari'at dalam soal perkawinan digantikan oleh hukum Swiss. Dengan demikian perkawinan tidak lagi dilakukan menurut syari'at, tetapi menurut hukum sipil, dan dalam masalah perceraian, wanita mendapat hak yang sama dengan pria. Demikian pula dalam hukum dagang, hukum pidana, hukum laut, dan hukum obligasi digunakan hukum Barat yang disesuaikan dengan kebutuhan rakyat Turki.

Pada tahun 1928, artikel tambahan dari konstitusi 1921 itu pun dihilangkan dan diganti dengan prinsip sekularisasi yang dimasukkan dalam konstitusi 1937. ${ }^{33}$ Dengan demikian Turki resmi menjadi negara sekuler. Walaupun demikian umat Islam tetap merupakan mayoritas dan bebas melakukan ajaran agama. Konstitusi Turki yang berlaku sejak tahun 1961, mengatur agama baik dalam teksnya maupun dalam rujukannya kepada serangkaian hukum organis menyangkut sekularisasi yang merupakan bagian dari hukum negara sejak tahun 1920-an. Konstitusi secara tegas tidak memperkenankan hukum organis yang meyangkut sekularisasi ini dijadikan sasaran tinjauan hukum dengan merintangi amandemen dan modifikasinya, karena hukum ini mengabadikan kepada prinsip sekularisasi. Hukum-hukum tersebut adalah :

1) Hukum tentang penyatuan pendidikan yang dikeluarkan pada tahun 1924.

2) Hukum tentang pemakaian topi yang dikeluarkan pada tahun 1925.

3) Hukum tentang penghapusan tekye dan zawiyat (asrama dan tempat ibadah sufi).

\footnotetext{
${ }^{32}$ Harun Nasution, pembaharuan.., hlm. 149-150

${ }^{33}$ Ibid.
} 
TAHKIM, Jurnal Peradaban dan Hukum Islam. Vol.2 No.l (Maret, 2019) | ISSN : 2597-7962

4) Ketentuan dalam hukum sipil yang berhubungan dengan perkawinan sipil.

5) Hukum tentang penggunaan angka internasional.

6) Hukum tentang abjad Latin yang dikeluarkan pada tahun 1928.

7) Hukum tentang penghapusan gelar efendi, bey, pasya, dan sebagainya.

8) Hukum yang melarang pemakaian pakaian-pakaian tertentu yang dikeluarkan pada tahun 1927.

Tidak semua undang-undang organis mengenai sekularisasi disebutkan dalam konstitusi tahun 1961, seperti penghapusan kekhalifahan yang telah dilakukan pada tahun 1924. Dan di antaranya yang telah dicabut adalah undangundang penggunaan bahasa Turki dalam azan (1931) dan larangan berziarah ke makam-makam suci. Dengan demikian azan kembali bisa dikumandangkan dalam bahasa Arab di bumi Turki. Namun demikian sekularisasi yang berlaku secara langsung tidak mampu ditantang oleh para kelompok Islam. Hal inilah yang menyebabkan ketegangan antara sekularisasi dan kesepakatan back to Islam menjadi masalah yang berkepanjangan.

Meskipun Turki merupakan negara sekuler, namun pertumbuhan keagamaannya sangat mencolok bagi sebagaian besar warga Turki. Hal ini bisa dilihat dari banyaknya penduduk yang menjadi anggota sekte-sekte keagamaan, seperti sekte Nur yang didirikan oleh Said Nursi sampai beranggotakan sekitar 300.000 orang. Dan dalam bidang sarana keagamaan, sekarang Turki memiliki tidak kurang dari 62.000 masjid dan pembangunan masjid mencapai 1.500 buah per tahun. Selain itu telah dibangun lebih dari 2.000 unit sekolah Al-Quran.

Adapun isu keislaman di Turki harus dipahami kaitannya dengan perubahan sosial dan persaingan politik yang bersifat pluralistik. Di dalam negara Turki kontemporer, tradisi ulama perkotaan sebagian besar telah hancur dan tidak lagi berpengaruh terhadap kehidupan masyarakat. Ideologi republik adalah sekuler, sementara kalangan atasan komitmen terhadap idiologi sekuler tersebut. Kelas terdidik perkotaan dari kalangan atasan Turki memandang Islam sebagai simbol keterbelakangan. Sebaliknya, tradisi Sufi-pedalaman tetap bertahan dan loyalitas keislaman masyarakat umum belum pernah tergoyahkan warga Turki senantiasa mengidentifikasikan diri sebagai muslim. 
TAHKIM, Jurnal Peradaban dan Hukum Islam. Vol.2 No.l (Maret, 2019) | ISSN : 2597-7962

Selanjutnya, tekanan ekonomi dan politik era pasca perang menimbulkan bangkitnya sejumlah gerakan dan partai yang komitmen terhadap re-Islamisasi negara dan masyarakat. Di antara yang paling besar adalah gerakan Said Nursi yang meraih pengaruh besar sebagai gerakan bawah tanah di Turki, sekalipun pemerintah berusaha keras melawan dan menghukum lantaran agitasi keagamaannya yang telah membangkitkan kembali semangat perjuangan Islam. Melihat perkembangan tersebut, dapatlah dikatakan bahwa Turki sebagai negara sekuler, tetapi belum 100\% sekuler, karena Republik Turki Mustafa Kemal masih mengurus soal agama melalui Departemen Urusan Agama, sekolah-sekolah Pemerintah untuk imam dan khatib, dan fakultas Ilahiyat dari perguruan tinggi Negara, Universitas Istambul.

Setelah Mustafa Kemal meninggal pada tahun 1938, usaha pembaharuannya dijalankan terus oleh para pengikutnya. Namun dua tahun kemudian, timbul gerakan "back to Islam" dari masyarakat dan menghasilkan karya yang nyata, yaitu pada tahun 1949 pendidikan agama dimasukkan kembali ke dalam kurikulum sekolah, dan pendidikan agama bersifat wajib. Mulai tahun 1950, orang-orang Turki telah dibolehkan naik haji ke Mekah. Tarekat yang selama ini tetap mempunyai pengikut besar secara rahasia di kalangan petani dan buruh, mulai berani meonjolkan diri. Demikian pula dalam bidang politik, Islam juga telah memulai memainkan peranan. ${ }^{34}$ Hal ini membuktikan bahwa sekularisme Mustafa Kemal tidaklah menghilangkan agama Islam dari masyarakat Turki, ia hanya bermaksud menghilangkan kekuasaan agama dari bidang politik dan pemerintahan.

\section{Hukum Keluarga di Indonesia}

Di Indonesia, hukum keluarga ini tercantum dalam Undang-Undang No. 1 tahun 1974 tentang pekawinan, Peraturan Pemerintah No. 9 Tahun 1975 tentang pelaksanaan UU No. 1 Tahun 1974 tentang perkawinan dan Kompilasi Hukum Islam (KHI). Dalam UU tersebut, urusan tentang pernikahan, perceraian, perwakinan bertingkat, dan segala hal yang berkaitan dengan keluarga tercantum di dalamnya. hal ini disempurnakan dengan KHI yang

${ }^{34}$ Ibid., hlm. 154 
TAHKIM, Jurnal Peradaban dan Hukum Islam. Vol.2 No.l (Maret, 2019) | ISSN : 2597-7962

memiliki tiga bab buku yang masing-masing memiliki bahasan yang berbeda. Sejarah pembentukan UU No. 1 Tahun 1974, PP. No. 9 Tahun 1975 dan KHI menunjukkan bahwa sumber utama yang mendominasi ketiga hukum keluarga tersebut adalah hukum Islam, hal ini bisa dilihat dari Pasal-Pasal yang ada didalamnya dan sejarah proses pembahasannya.

Undang-Undang Nomor 1 Tahun 1974 tentang perkawinan (UUP), yang terdiri dari 14 bab dan 67 Pasal, Peraturan Pemerintah (PP) Nomor 9 Tahun 1975 tentang pelaksanaan UU No. 1 Tahun 1974 tentang perkawinan, dan Instruksi Presiden RI Nomor 1 Tahun 1991 tentang Kompilasi Hukum Islam (KHI) yang terdiri dari Buku I tentang Hukum Perkawinan, Buku II tentang Hukum Kewarisan dan Buku III tentang Hukum Perwakafan. Ketiga peraturan perundang-undangan tersebut merupakan sumber hukum materiil yang menjadi rujukan utama hukum keluarga di lingkungan Peradilan Agama sebagai pengadilan yang salah satu kewenangannya menangani masalah-masalah hukum keluarga bagi orang yang beragama Islam.

Dalam UUP di antaranya adalah Pasal 2 tentang pencatatan nikah; Pasal 3, 4 dan 5 tentang poligami; Pasal 7 tentang usia pernikahan; Pasal 11 tentang masa tunggu bagi istri yang putus perkawinannya (iddah); Pasal 31 tentang hak dan kedudukan suami istri; dan Pasal 34 tentang kewajiban suami istri.

Sementara dalam KHI adalah dalam Buku I diantaranya Pasal 14 tentang pencatatan nikah; Pasal 25 tentang kesaksian perempuan dalam perkawinan; Pasal 15 tentang batas minimal usia perkawinan; Pasal 79 tentang kedudukan suami isteri; Pasal 80 tentang pencarian nafkah; Pasal 55-59 tentang poligami; Pasal 153 tentang Iddah; Pasal 84 tentang nusyuz (membangkang dari kewajiban); dan Pasal 163 tentang hak rujuk. Dalam Buku II diantaranya adalah Pasal 186 tentang anak diluar perkawinan, dan Pasal 176 tentang pembagian waris bagi anak laki-laki dan perempuan.

Lebih rinci, kandungan tentang Undang-undang RI No. 1 tahun 1974 Tentang Perkawinan:
a. Bab I; Dasar Perkawinan
b. Bab II; Syarat-syarat perkawinan
c. Bab III; Pencegahan perkawinan 
TAHKIM, Jurnal Peradaban dan Hukum Islam. Vol.2 No.l (Maret, 2019) | ISSN : 2597-7962

d. Bab IV; Batalnya perkawinan

e. Bab V; Perjanjian perkawinan

f. Bab VI; Hak dan kewajiban suami istri

g. Bab VII; Harta benda dalam perkawinan

h. Bab VIII; Putusnya perkawinan serta akibatnya

i. Bab IX; Kedudukan anak

j. Bab X; Hak dan kewajiban antara orang tua dan anak

k. Bab XI; Perwalian

1. Bab XII; Ketentuan-ketentuan lain

m. Bab XIII; Ketentuan peralihan

n. Bab XIV; Ketentuan penutup

Ketentuan-ketentuan tentang hukum keluarga yang secara khusus mengatur orang muslim tercantum dalam Kompilasi Hukum Islam (KHI) pada Buku I hukum perkawinan. Buku I KHI berisi tentang seluk beluk perkawinan, sehingga memiliki Pasal-Pasal yang banyak. Secara keseluruhan berisi 19 Bab dan 170 Pasal. Lebih rincinya adalah sebagai berikut:

Pada Bab I berisi tentang ketentuan umum dan terdiri 1 Pasal. Pada bab ini dijelaskan tentang definisi-definisi operasional, seperti pengertian peminangan, akad nikah, wali, taklik talak, dan yang berhubungan dengan perkawinan. Bab II tentang dasar-dasar perkawinan dan berisi 10 Pasal. Pada bab ini, dijelaskan dasar-dasar perkawinan, seperti perkawinan menurut Islam, tujuan perkawinan, perkawinan yang sah, dan lain-lain yang berkaitan dengan dasar perkawinan. Menurut Pasal 4, perkawinan Sah apabila dilakukan menurut hukum Islam sesuai dengan Pasal 2 ayat (1) Undang-undang No 1 tahun 1974 tentang perkawinan.

Bab III berisi tentang peminangan. Dalam bab ini terdiri dari 3 Pasal yang membahas tentang peminangan, seperti tatacara peminangan, proses peminangan, akibat hukum peminangan, dan putusnya peminangan. Seperti Pasal 13 ayat (1) disebutkan bahwa peminangan belum menimbulkan akibat hukum dan para pihak bebas memutuskan hubungan pinangan.

Berikutnya adalah Bab IV yang membahas tentang rukun dan syarat perkawinan. Pada bab IV ini berisi dibagi menjadi lima bagian, yaitu bagian 
TAHKIM, Jurnal Peradaban dan Hukum Islam. Vol.2 No.l (Maret, 2019) | ISSN : 2597-7962

kesatu membahas tentang rukun, bagian kedua calon mempelai, bagian ketiga wali nikah, bagian keempat saksi nikah, dan bagian kelima adalah akad nikah. Dalam bab ini juga berisi 16 Pasal yang berkaitan dengan syarat dan rukun nikah, yaitu calon mempelai, wali nikah, dan akad nikah. Bab V berisi tentang mahar. Pasal 30 pada bab ini dijelaskan bahwa calon mempelai pria wajib membayar mahar kepada calon mempelai wanita yang jumlah, bentuk dan jenisnya disepakati oleh kedua belah pihak.

Bab VI berisi tentang larangan kawin. Bab ini berisi 6 Pasal yang berkaitan dengan larangan kawin baik bagi laki-laki maupun perempuan. Bab VII berisi tentang perjanjian perkawinan. Pada bab ini berisi 8 Pasal yang berkaitan dengan perjanjian perkawinan. Bab VIII berisi tentang kawin hamil. Dalam Pasal 53 dijelaskan bahwa seorang wanita hamil di luar nikah dapat dikawinkan dengan pria yang menghamilinya.

Bab IX berisi tentang beristri lebih dari satu orang. Bab ini berisi 5 Pasal yang menjelaskan tentang kebolehan beristri lebih dari satu, alasan dan tatacaranya. Bab X berisi tentang Pencegahan Perkawinan. Pada bab ini memuat 10 Pasal yang berkaitan dengan pendegahan perkawinan. Seperti Pasal 60 menyatakan bahwa:

(1) Pencegahan perkawinan bertujuan untuk menghindari suatu perkawinan yang dilarang hukum Islam dan peraturan perundangundangan

(2) pencegahan perkawinan dapat dilakukan bila calon suami atau calaon istri yang akan melangsungkan perkawinan tidak memenuhi syarat-syarat untuk melangsungkan perkawinan menurut hukum Islam dan peraturan perundang-undangan.

Bab XI berisi batalnya perkawinan. Bab ini memuat 7 Pasal, diantaranya Pasal 71 yaitu:

Suatu perkawinan dapat dibatalkan apabila:

a. Seorang suami melakukan poligami tanpa izin Pegadilan Agama

b. Perempuan yang dikawini ternyata kemudian diketahui masih menjadi istri pria lain yang mafqud

c. Perempuan yang dikawini ternyata masih dalam iddah suami lain 
TAHKIM, Jurnal Peradaban dan Hukum Islam. Vol.2 No.l (Maret, 2019) | ISSN : 2597-7962

d. Perkawinan yang melanggar batas umur perkawinan sebagaimana ditetapkan dalam Pasal 7 undang-undang No 1 tahun 1974

e. Perkawinan dilangsungkan tanpa wali atau dilaksankan oleh wali yang tidak berhak

f. Perkawinan yang dilaksanakan dengan paksaan

Bab XII berisi hak dan kewajiban suami Istri. Bab XIII berisi harta kekayaan dalam perkawinan, Bab XIV pemeliharaan anak, Bab XV Perwalian, Bab XVI Putusnya perkawinan, Bab XVII akibat putusnya perkawinan, Bab XVIII Rujuk, dan Bab XIX masa berkabung.

\section{SIMPULAN}

Hukum keluarga yang terdapat di negara Turki dengan Indonesia sejatinya sudah mapan. Setiap Pasalnya sudah mengakomodir kebutuhan dan permasalahan yang terdapat dalam keluarga. Hukum Keluarga yang ada di Indonesia tercantum dalam UU No. 1 Tahun 1974, PP. No. 9 Tahun 1975 serta Kompilasi Hukum Islam. Adapun hukum keluarga di Turki tercantum dalam Hukum tentang hak-hak keluarga (The Ottoman Law of Family Rights / Qanun al-huquq al-Aila) yang dirintis sejak tahun 1915, kemudian diundangkan pada tahun 1917. 
TAHKIM, Jurnal Peradaban dan Hukum Islam. Vol.2 No.l (Maret, 2019) | ISSN : 2597-7962

\section{DAFTAR PUSTAKA}

Abdurrahman bin Qasim, (1412 H.), Majmu Fatawa Syaikh al-Islam Ibnu Taimiyyah, Dar Alam al-Kutub

Azizy, A. Qodri A. (2004). Hukum Nasional: Eklektisisme Hukum Islam \& Hukum Umum. Jakarta: Teraju

Anderson, J. N. D. (1994). Islamic Law in the Moderen World, diterjemahkan oleh Mahmud Husain dengan judul Hukum Islam di Dunia Modern Cet. I, Yogyakarta: Tiara Wacana Yogya.

Hanafi, Ahmad. (1989). Pengantar dan Sejarah Hukum Islam, Cet. V. Jakarta: PT. Bulan Bintang.

Hasan Khalil, Rasyad, (2009). Tarikh Tasyri', Sejarah Legislasi Hukum Islam. Jakarta: Amzah.

Hoeve, Van. (1994). Ensiklopedi Islam. Jakarta: PT. Ichtiar Baru.

Manna' al-Qaththan, (1422). at-Tasyri' wa al-Fiqh fi al-Islam Tarikhan wa Manhajan, Maktabah Wahbah.

Mubarok, Jaih, (2003). Sejarah dan Perkembangan Hukum Islam, Bandung: PT Remaja Rosdakarya.

Mughni, Syafiq A. (1997). Sejarah Kebudayaan Islam di Turki, Cet. I, Jakarta: PT. Logos Wacana Ilmu.

Mushtafa az-Zarqa, (1418 H.). al-Madkhal al-Fiqh al-Am, Dar al-Qalam.

Muzhdar, Atho \& Khairuddin Nasution, (2003). Hukum Keluarga di Dunia Islam Modern. Jakarta: Ciputat Press.

Nasution, Harun. (1991). Pembaharuan dalam Islam; Sejarah Pemikiran dan Gerakan. Jakarta: Bulan Bintang.

Roibin, (2010). Penetapan Hukum Islam dalam Lintasan Sejarah, Malang: UINMaliki Press.

Swiss al-Mahamid, Masirah a-Fiqh al-Islami al-Mu'ashir, (1422 H.). Jam'iyyah Ummal al-Mathabi'.

Wahab Khalaf, Abdul, (2002). Sejarah Pembentukan dan Perkembangan Hukum Islam, Jakarta: PT Raja Grafindo Persada. 
TAHKIII, Jurnal Peradaban dan Hukum Islam. Vol.2 No.l (Naret, 2019) | ISSN : 2597-7962

Yatim, Badri. (1999). Sejarah Peradaban Islam. Jakarta: PT. Raja Grafindo Persada. 
TAHKIII, Jurnal Peradaban dan Hukum Islam. Vol.2 No.l (Naret, 2019) | ISSN : 2597-7962 